\title{
Comparative Study on Plant Type Specific LED Light Source Design Parameters
}

\author{
Csaba Kárász*, József Kopják \\ Óbuda University, Kandó Kálmán Faculty of Electrical Engineering, Bécsi út \\ 96/b, H-1034 Budapest, Hungary, karasz.csaba@cl.uni-obuda.hu*, \\ kopjak.jozsef@kvk.uni-obuda.hu
}

\begin{abstract}
The aim of this study is to highlight the correlations among the main parameters of lighting systems, for the agricultural industry. With these data, engineers could enhance the efficiency of their light source, in regards to different plant types. Statistical analysis has been conducted on the results of several experiments to find out if there is any correlation among different LED driver settings, which could affect light source design. The experiments have been re-grouped according to plant types and used variables. Two major groups have been examined: the experiments made with lettuce and with microalgae (in which most studies were made in the topic of photo-bioreactor enhancement). Smaller, sub-groups, have been clustered together with similar test variables as well. Significant correlations have been found between the variables of: light intensity (photosynthetic photon flux density) and photoperiod, light intensity and frequency, and light intensity and light spectrum as well. The results are in congruence with other studies and the summary of the analysis could be used to optimize light source design.
\end{abstract}

Keywords: Indoor Plant Cultivation; PPFD; Photosynthesis; Pulse Width Modulation, LED light source driver

\section{Introduction}

Production efficiency is more and more crucial on the field of agriculture. Sunlight is dependent on weather conditions, time of the season and other time and place dependent parameters. Therefore, artificial light has to be provided to enhance or substitute natural light in plant production.

This paper highlights the relationship between pulse width modulated (PWM) LED light source system parameters such as wavelength, frequency, duty cycle and light intensity (PPFD). This information provides support for engineers who are involved in plant factory design process.

Different types of light sources are used to enhance plant growth in agriculture, but light emitting diode (LED) could be the optimal choice. Its response time is 
quite fast, has much longer lifetime, very good controllability and has very good efficiency. Also, LEDs radiate electromagnetic waves in a quite narrow wave band. This attribute could give a perfect solution to "assemble" the spectrum necessary for most applications [38].

Different plants might need different light source settings. If the correlation among different light source parameters could be known plant specifically, the control of light sources could be optimized. It would be possible to use less electricity and to achieve better plant quality and quantity. The effect of change of different parameters of light source on plant growth have been examined by previous researches. The following variables were tested in previous studies: duty cycle, frequency, wavelength, light intensity, photoperiod and phase difference of different wavelengths of a light source. However, only few of these parameters have been examined in the same experiment. Jao et al. [21] [22] tested different combinations of duty cycle, frequency and photoperiod, while Mori et al. [28] and Park et al. [34] checked frequency and duty cycle (Table 3). Lot of experiments made to find out the results of frequency change (Kanechi, M. [25], Son, K.-H. et al., [45], Jannsen M.G.J. [20], Vejrazka, C. et al., [49]). Others checked wavelength (light color) difference (Pardo, G.P. et al. [33], Yago, T. et al. [52] [53]) and the phase difference between different wavelengths of light (Shimada, A. et al. [44]) or the combination of them (Senol, R. et al. [40] [41]). Timothy, M. et al. [48] checked the effect of light intensity change (via the help of the change of duty cycle). Berkovich, Y. A. et al. [6] summarized the results of studies and experiments.

Usually, only a few parameters are tested in a research. In this paper a statistical analysis is introduced to be used on already performed experiment data to synthesize their best results. It would be easier to optimize the parameters of PWM driven light sources and save energy cost with the found correlations. Based on this information, depending on the aim of a cultivation facility (which plant types to grow), it is possible to enhance the feasibility of a plantation.

In the plant photosynthesis part, the light quality needs of plants are investigated. This information is vital to achieve perfect light conditions for plants and to be able to interpret data in a statistical analysis. It is possible to reach (or go beyond) the (photosynthetic) saturation levels (photoinhibition) [10] under optimal conditions. In the present paper the effects of electromagnetic radiation on plants are categorized according to PWM controlled LED light parameters. Part of the raw data is taken from a previous article [24] and used from an entirely new point of view. This way the analyzed parameters could be viewed from an engineering (PWM drive) point of view.

Photosynthetic photon flux density (PPFD), is the measure of light energy arriving to plants. In the PPFD parameter calculation section of the paper, it is highlighted how to convert light source parameters according to the processes of plant photosynthesis procedures. 
The plant specific light source parameter part shows the results of the compared studies. It gives information about optimal LED driver settings (PWM duty cycle, frequency etc.) for specific plants.

The statistical analysis part introduces the used analysis methods to achieve a synthesis of the analyzed experiments.

In the last part of the paper, the results of the statistical analysis are highlighted and the findings of the study are summarized in the conclusion. This procedure could give support to the realization of a more efficient PWM driven LED light source design for plant cultivation.

\section{The Photosynthesis of Plants}

\subsection{The Effect of Different Light Wavelengths on Plants}

\subsubsection{The Light Sensors of Plants - Photoreceptors}

Photoreceptors in plants mostly not just sense light but absorb it as well - and according to their types, they absorb different band of light. These photoreceptors transmit - transduce signals to the crops to be able to change their structure.

Several photoreceptor signals work together, which result in plant response or in a morphological change of the plant. These are the phytochromes, cryptochromes, rhodopsins, xanthopsins and phototropin (light-oxygen-voltage (LOV) sensors) [29]. The newest discovered photoreceptor is the UV resistance locus 8, which absorbs UV-B light [6].

It is important to find a photoreceptor signal's effect and also have to find a way to stimulate the photoreceptor with light.

\subsubsection{The Energy Harvesters of Plants - Photosynthetic Pigment Groups}

In plants photoreceptors and the materials which are contained in their cells/structure are effected by light as well. The chloroplast has several parts absorbing electromagnetic waves and reacting to it. Only certain parts of the electromagnetic spectrum affect them and only certain parts of it are absorbed by them. As a consequence of the "color" sensitivity of the chloroplast, it has a certain color as well: therefore they can be called pigments [5]. They are responsible for different metabolic processes of plants. These are photosynthesis, thermal balance, etc..: the state of the plant and its behavior [12] [5]. 
Since pigments absorb light in certain wavebands only, it is possible to group them accordingly. Chlorophylls, Phycobilins and Carotenoids are the major pigment groups.

Chlorophyll is one of the major pigment group, consists of "Chlorophyll a" and "b", (c1, c2 and d). It consists of a phytol tail and a porphyrin ring, which respectively captures light. With its electrons activates the photosynthesis. "Chlorophyll b" absorbs a different band of light and helps "Chlorophyll a" with its energy. It reacts to green (450-475 [nm]) and orange-red (630-675 [nm]) light. Chlorophyll content increases when R : FR ratio increases - that is also the time when photosystem II to photosystem I decreases (PSII/PSI) [14].

Carotenoids have the task to deal with the excess of light. They protect other pigments (Chlorophylls at first place) and absorb light from the blue (400 [nm]) until the green $(550[\mathrm{~nm}])$ band.

Phycobilins are present mostly in cyanobacteria and red microalgae. They replace the accessories of Chlorophyll in terms of light absorption accessory - antennae. They absorb light bands in the blue, green, yellow or orange $(400-650[\mathrm{~nm}])$ parts [27].

Table 1

Photopigment sensitivity to different bands of electromagnetic stimulus. The effect of electromagnetic stimulus on plant morphology

\begin{tabular}{|l|c|c|}
\hline \multicolumn{1}{|c|}{$\begin{array}{c}\text { Photopigment } \\
\text { name }\end{array}$} & Color Sensitivity & Area controlled / effected by the pigment \\
\hline $\begin{array}{l}\text { Chlorophyll a, b } \\
\text { (c1,c2,d) }\end{array}$ & $\begin{array}{l}\text { green }(450-475 \mathrm{~nm}) \text { and } \\
\text { orange-red }(630-675 \mathrm{~nm})\end{array}$ & $\begin{array}{c}\text { Captures light, and with its electrons } \\
\text { activates the photosynthesis. Chlorophyll b } \\
\text { absorbs a different band of light and helps } \\
\text { Chlorophyll a with its energy. }\end{array}$ \\
\hline $\begin{array}{l}\text { Phycobilin } \\
\text { (primarily in } \\
\text { cyanobacteria and } \\
\text { red microalgae) }\end{array}$ & $\begin{array}{c}\text { blue, green, yellow or } \\
\text { orange (400-650 nm) }\end{array}$ & $\begin{array}{c}\text { They replace the accessories of Chlorophyll } \\
\text { in terms of light absorption accessory - } \\
\text { antennae. }\end{array}$ \\
\hline Carotenoid & $\begin{array}{c}\text { from the blue } \\
(400 \mathrm{~nm}) \text { until the green } \\
(550 \mathrm{~nm})\end{array}$ & $\begin{array}{c}\text { It deals with the excess of light - protecting } \\
\text { other pigments (Chlorophylls at first place). }\end{array}$ \\
\hline
\end{tabular}


Table 2

Photoreceptor sensitivity to different bands of an electromagnetic stimulus. The effect of electromagnetic stimulus on plant morphology

\begin{tabular}{|c|c|c|}
\hline Photoreceptor name & $\begin{array}{c}\text { Color } \\
\text { Sensitivity }\end{array}$ & $\begin{array}{c}\text { Area controlled / effected by the } \\
\text { receptor }\end{array}$ \\
\hline $\begin{array}{l}\text { Phytochrome (might be } \\
\text { complementer system with } \\
\text { Cryptochrome) ABCF/E }\end{array}$ & $\begin{array}{l}\text { Red : Far red } \\
\underline{\text { ratio }} \text { (shade) }\end{array}$ & $\begin{array}{l}\text { Early flowering - stem elongation, Fatty } \\
\text { acid regulation during seed maturation, } \\
\text { Chlorophyll and carotenoid increase - } \\
\text { Reduces during the End Of the Day }\end{array}$ \\
\hline $\begin{array}{l}\text { Cryptochrome (might be } \\
\text { complementer system with } \\
\text { Phytochrome) Cry1,Cry2 } \\
\end{array}$ & UV-A and Blue & Cell expansion reduction \\
\hline $\begin{array}{l}\text { Phototropin (light-oxygen- } \\
\text { voltage (LOV) sensor) } \\
\text { Phot1, Phot2 }\end{array}$ & Blue & $\begin{array}{c}\text { Chloroplast and leaf movement, stomatal } \\
\text { opening, phototropism, onset of flowering, } \\
\text { entrainment of the circadian clock, } \\
\text { regulate aspects of morphogenesis, , de- } \\
\text { etiolation }\end{array}$ \\
\hline Rhodopsin (in Microalgae) & $\begin{array}{l}\text { Light intensity } \\
\text { (color } \\
\text { independent) }\end{array}$ & Fototaxis direction indicator \\
\hline UVR8 (UV res. Locus 8) & UV-B & Light dependent gene expression reg. \\
\hline
\end{tabular}

Taken into account the above mentioned information, the following wavebands are the most important: UV-B, UV-A, blue, red and far-red light. However, green [6] [11], yellow and the orange band also affects plants (Table 2).

\subsection{The Speed of Different Processes in Photosynthesis}

The oxidization of water (via a tetra manganese cluster [51]) is the base of the whole photosynthesis. It gives the base material (electrons and protons) for the Electron Transport Chain (ETC). This process is in the thylakoid membrane of the chloroplast. The ETC process could be called an energy harvester procedure since photons activate it. The performance of the ETC could be characterized with the

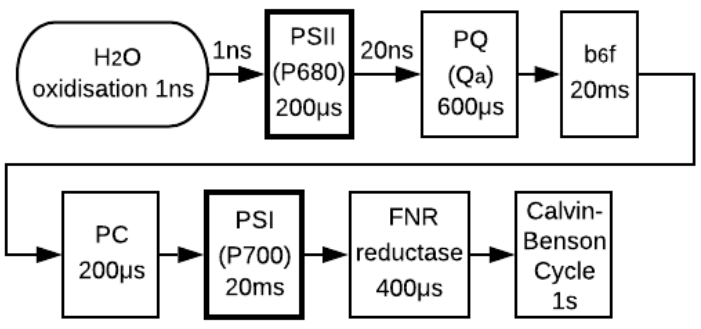

Figure 1

Process of the electron transport chain [25]

parameter called Linear Electron Flux (LEF) as well [5]: 
From the above showed processes the PSII and PSI reaction (centers) are the light (induced) reactive phases. It is important to take into account the speed of these processes. The frequency of light reaching these centers are essential in terms of the efficiency of photosynthesis. The speed of the reaction center PSII is approximately $200 \mu \mathrm{s}$ and the speed of PSI is $20 \mathrm{~ms}$ [25].

In parallel with these processes works the ATP synthase, but its reactions are nonphotochemical. Plants create adenozyne-tri-phosphate (ATP) with the help of the light reaction of photosynthesis. This gives energy to the plants in and also nicotinamide - adenine-dinucleotide-phosphate $\left(\mathrm{NADP}^{+}\right)$. It reduces power to organic materials. These are synthesized with the help of Photosystem II (P680), Photosystem I (P700) and ATP synthase.

The Calvin(-Benson) cycle happens in the thylakoid lumen and it could be one of the end phases of the energy conversion of photosynthesis. During this reaction happens the carbon assimilation. The created ATP and $\mathrm{NADPH}_{2}$ helps to assimilate $\mathrm{CO}_{2}$ into organic materials (recreate cells, or store it) [5] [5]. This process is directly independent of light. It is dependent on the processes (end products) of PSII and PSI, it is also indirectly dependent on light.

Mostly the harmony of the ETC process makes it possible for pulsed light to give better results than continuous light. This happens with the re-oxidation of the plastoquinin pool in the chloroplast/photosynthetic membrane. Higher photon flux density (PFD) could be reached - and with that higher quantities could be reached in plant production [30]. It is important to have an abundant supply of other input materials than light as well (depending on plant type: $\mathrm{CO}_{2}, \mathrm{H}_{2} \mathrm{O}, \mathrm{N}_{2}$, P etc...) [43]. Moreover, it is important to state, that there are studies which conducted research with the concentrated and pulsed light of the sun. The results of these studies showed that plant cultivation with pulsed sunlight gives better results than continuous sunlight [13]. Also, other studies state that sunlight itself can not arrive without interruption to most plants. Different obstructions are in their way, such as leaves on trees [25].

\subsection{Light Energy Required for Plants}

It is very important to note that light energy input for plants is very much connected with the daily light period used. The total daily amount of photons could be the same with longer photoperiod. For example, with 16/24 instead of 12/12 would need lower PPFD (i.e.: with this, the photoinhibition could be avoided).

The most efficient power level could be different at each type of plant. According to different researches, the minimum level of PPFD is $0.1\left[\mu \mathrm{molm}^{-2} \mathrm{~s}^{-1}\right]$ which is a measurement threshold [5], but the efficient PPFD usage could reach 1500 [ $\mu \mathrm{molm}^{-}$ $\left.{ }^{2} \mathrm{~s}^{-1}\right]$ as well [6]. However, common values are 200-300-400 [ $\left.\left.\mu \mathrm{molm}^{-2} \mathrm{~s}^{-1}\right]\right)$. The best solution is to use measurements to confirm the best illumination input. 
There are different ways to measure the level of photosynthesis in vivo. One indirect method is to measure the level of chlorophyll $a$ fluorescence with the help of a (portable) fluorimeter [5]. Although this factor belongs to the PSII center, it is correlated with the efficiency of the whole photosynthesis. With the measurement of the minimum and maximum level of fluorescence, it is possible to find the best operating efficiency of PSII.

The best possible power settings could be skewed by the indirect effects of other parts of the ETC on PSII. Such effects are the regeneration time, resource needs and assimilation rates of PSI center. Furthermore, ATP synthase and the Calvin Cycle (among others) could affect power settings. Furthermore, the effect of the environment of the plants have to be taken into account as well (possible abiotic stresses like gases present, temperature, humidity, nutrients) [9].

\section{PPFD Parameter Calculation from Flux of LED}

An LED is different from a diode in terms of its (emitting) nature. This emission is measured in luminous flux (photometric power [lm]) or radiant flux (radiometric value [W]). It is also characterized by the wavelength of the emitted light [nm].

In the UV and IR bands the radiance: the intensity of the emission is represented by the SI unit of radiometric flux: $\Phi_{\mathrm{e}}$; watt $[\mathrm{W}]$ or $[\mathrm{mW}]-$ which is a radiometric value.

Component catalogues use the SI unit of Luminous flux: $\Phi_{\mathrm{v}}$, lumen [lm] as the measurement unit for the emission values in the visible region of the electromagnetic wave spectrum. This is a photometric value, representing luminous energy (which has a visible - luminous - nature). This parameter is based on the photopic response of the human eye (relative spectral sensitivity function $(\mathrm{V}(\lambda)$ ) [33]). The photoreceptors of the human visual perception differ from plants (in functionality and responses as well). There are two main groups of photoreceptors in the human eye: rods and cones. Rods are incapacitated (saturated) during daylight conditions. Cones function as the main tool of visual perception, which is called a photopic response [39].

The radiometric flux parameter $\left(\Phi_{\mathrm{e}},[\mathrm{W}]\right)$ of light source could be calculated from its photometric parameter $\left(\Phi_{\mathrm{v}},[\mathrm{lm}]\right)$. The calculations are detailed in several books and articles [36] [38]. The relative spectral sensitivity function $(\mathrm{V}(\lambda))$ has to be used as a weighting factor and could be calculated via a non-linear regression (like in [47]). The conversion from luminous flux to radiometric flux data involves a wavelength parameterized component. Because of this, it is necessary to integrate the results of the whole band (the whole emission source spectral band of a component) [36]. 
Although, this value gives information only about the light source performance. In terms of plant cultivation, one has to be able to control the number of photons per second arriving at an area (plant surface), because photosynthesis is activated (energized) via photons.

The parameter which is used for this purpose is the Photosynthetic Photon Flux Density (PPFD), which is the measure of the number of photons arriving at a unit area during a unit time $\left[\mu \mathrm{molm}^{-2} \mathrm{~s}^{-1}\right]$.

PPFD could be calculated via the help of spectral irradiance $\left(\mathrm{E}_{\lambda}(\lambda)\right)[37]$ :

$P P F D=\frac{10^{6}}{h c N_{A}} \int_{400}^{700} E_{\lambda}(\lambda) d \lambda$

where $\mathrm{h}$ is the Planck's constant $\left(6.626 \times 10^{-34}[\mathrm{Js}]\right), \mathrm{c}$ is the speed of light $(3.00 \times$ $\left.10^{8}\left[\mathrm{~ms}^{-1}\right]\right)$ and $\mathrm{N}_{\mathrm{A}}$ is the Avogadro's number $\left(6.023 \times 10^{23}\right)$.

Spectral irradiance $\left(\mathrm{E}_{\lambda}(\lambda)[1]\right)$ is a combination of absolute irradiance and spectral power distribution (SPD) [37]:

$E\left(\lambda_{1}, \lambda_{2}\right)=\int_{\lambda_{1}}^{\lambda_{2}} E_{\lambda}(\lambda) d \lambda$

Spectral power distribution is included in the datasheet of the emitters. It is a ratio number over a spectrum band (different wavelengths $(\lambda)$ ).

Absolute irradiance (flux density): E, $\left[\mathrm{Wm}^{-2}\right]$ could be calculated with the help of radiant intensity, but this solution could be used only if the distance between the emitter and the irradiated surface is large enough. In this way it would not deviate from the inverse-square law (and if we assume that the emitter could be modelled with a Lambertian source model [1]): I, [W sr ${ }^{-1}$ [36].

$E_{e}=\frac{I_{\text {e }}}{A}=\frac{I_{\text {e }}}{r^{2}} ;\left[W / m^{2}\right]=\frac{[W / s r]}{\left[m^{2}\right]}$

The radiant intensity $\left(\mathrm{I},\left[\mathrm{Wsr}^{-1}\right]\right)$ could be calculated from the radiometric flux $\left(\Phi_{\mathrm{e}}\right.$, $[\mathrm{W}]$ ) and with the help of the solid angle $(\Omega)$ parameter of the emitter [36].

$\Omega=\frac{A}{r^{2}}=\frac{2 \pi h}{r}=2 \pi\left[1-\cos \left(\frac{\alpha}{2}\right)\right]$

Where $\alpha$ is the viewing angle in terms of emitters (LED). Based on the viewing angle of the emitter, the radiant intensity: $\mathrm{I}_{e},\left[\mathrm{Wsr}^{-1}\right]$ for a given waveband could be calculated. The calculation will need the radiometric flux $\left(\Phi_{\mathrm{e}},[\mathrm{W}]\right)$ and the solid angle $(\Omega)$ parameters as well [36]: 


$$
I_{\theta}=\Phi_{\theta} / \Omega ;[W / s r]=[W] /[s r]
$$

Therefore, we can conclude that under certain conditions (the usage of Lambertian modelling is possible) one can predict the PPFD to a certain extent with an error margin.

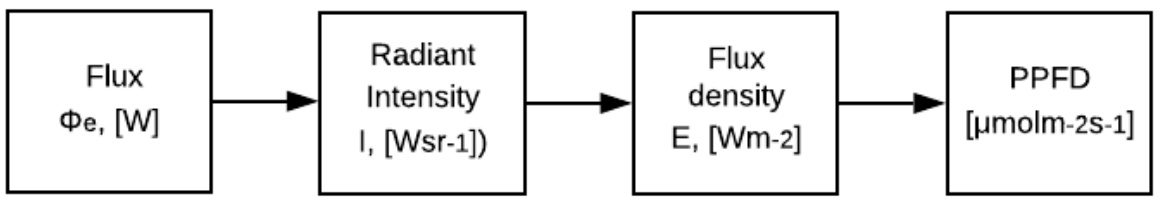

Figure 2

Process of the conversion

It is important to note, that in cases where the Lambertian model is not applicable, one can arrive at false conclusions with the usage of the above model. Safe results could be achieved via the usage of validating measurements on the used emitters.

Usually, PPFD is measured via the usage of (photon) quantum sensors (in $[\mu \mathrm{molm}-$ ${ }^{2} \mathrm{~s}^{-1}$ ]) such as the LI-COR 190. This machine is quite expensive and gives information only about the PPFD of the location point, where the quantum sensor is placed because it is not feasible and possible to use in a larger plantation area. On the other hand, it is possible to use a much cheaper solution described by Sato and Tsukada: a simple digital camera could give a solution to find the PPFD of the used emitters [37].

\section{Plant Specific Light Source Parameters of Analyzed Studies}

There are many factors that affect the growth of plants besides light quality. Such parameters are the ground medium, fertilization (amount and mixture type), air exchange ratio, $\mathrm{O} 2$ and $\mathrm{CO} 2$ levels, air humidity, temperature and light source distance. Several papers - experiments were gathered to find trends among light source settings. The mentioned input variables and the output variables of the examined experiments are not included in this paper due to space limitations. Only the setup parameters of the best results are taken to use them as the base of a statistical analysis to find relationships among them. Mainly non-parametric tests were chosen because of the non-related nature of the examined values. Parametric tests were used in the cases where the data had certain (normal) distribution 
LED based light source driver setup data of previous projects

Variable abbreviations: F - Frequency, D- Duty cycle, Pho - Photoperiod, I - Light intensity, Pha - Phase shift of different wavelengths, W - Wavelength

\begin{tabular}{|c|c|c|c|c|c|c|c|}
\hline$\frac{\text { Research }}{\underline{\text { ID }}}$ & $\underline{\text { Type of plant }}$ & $\frac{\text { LED light }}{\underline{\text { spectrum }}}$ & $\frac{\text { Freq. }}{[\mathrm{Hz}]}$ & $\frac{\text { Duty }}{\text { cycle }}$ & $\frac{\text { PPFD }}{\frac{(\mu \mathrm{molm}}{\left.\underline{-2} \mathrm{~s}^{-1}\right)}}$ & $\frac{\text { Varia }}{\underline{\text { bles }}}$ & $\frac{\underline{\text { Daily }}}{\text { photope }}$ \\
\hline $\begin{array}{l}\text { [21] Jao et } \\
\text { al. - 2003 }\end{array}$ & $\begin{array}{c}\text { Potato - } \\
\text { Solanum T. L. }\end{array}$ & $\begin{array}{c}9 \text { red } 645+-20 \mathrm{Nm} \text {, } \\
4 \text { blue } 460+-20 \\
\mathrm{Nm} \\
\end{array}$ & 720 & 50 & 120 & $\begin{array}{c}\mathrm{FDPh} \\
\mathrm{o}\end{array}$ & $16 / 8$ \\
\hline $\begin{array}{l}\text { [22] Jao et } \\
\text { al. -2004 }\end{array}$ & $\begin{array}{c}\text { Potato - } \\
\text { Solanum T. L. }\end{array}$ & $\begin{array}{c}9 \text { red } 645+-20 \mathrm{Nm} \text {, } \\
4 \text { blue } 460+-20 \\
\mathrm{Nm} \\
\end{array}$ & 720 & 50 & 120 & $\begin{array}{c}\text { FDPh } \\
\text { o }\end{array}$ & $16 / 8$ \\
\hline $\begin{array}{c}17] \\
\text { Hernández } \\
\text { et al.- 2014 }\end{array}$ & $\begin{array}{l}\text { Cucumber-C. } \\
\text { s. 'Cumlaude' }\end{array}$ & Red $-661[\mathrm{Nm}]$ & 2500 & $50 * *$ & 60 & $\mathrm{D}$ & $18 / 6$ \\
\hline $\begin{array}{l}\text { [28] Mori et } \\
\text { al. -2002 }\end{array}$ & $\begin{array}{c}\text { Lettuce - } \\
\text { Lactuca sativa } \\
\text { L. }\end{array}$ & $\begin{array}{c}10 X 20 / 10 X 40 \\
\text { Clear White }\end{array}$ & 2500 & 33 & 50 & DPho & 24 \\
\hline $\begin{array}{l}\text { [25] Kanech } \\
\text { i et al. -2016 }\end{array}$ & $\begin{array}{c}\text { Lettuce - } \\
\text { Lactuca sativa } \\
\text { L. }\end{array}$ & $\begin{array}{l}\text { red and blue, } \\
660: 455 \mathrm{~nm}=4: 1\end{array}$ & 10000 & 50 & 200 & $\mathrm{~F}$ & $16 / 8$ \\
\hline $\begin{array}{l}\text { [33] Pardo } \\
\text { et al -2016 }\end{array}$ & $\begin{array}{c}\text { Lettuce - } \\
\text { Lactuca sativa } \\
\text { L. }\end{array}$ & $\begin{array}{l}4 \text { red LEDs } \\
(600-650 \mathrm{~nm})\end{array}$ & 50 & 20 & $\begin{array}{c}\text { 240lu } \\
\text { mens/1 } \\
\text { amp }\end{array}$ & W & $12 / 12$ \\
\hline $\begin{array}{l}\text { [23] Jishi et } \\
\text { al. -2012 }\end{array}$ & $\begin{array}{c}\text { Lettuce - } \\
\text { Lactuca sativa } \\
\text { L. } \\
\end{array}$ & 196 white LED & 100 & 75 & 133,3 & FD & $16 / 8$ \\
\hline $\begin{array}{l}{[8] \text { Cho et }} \\
\text { al. }-2013\end{array}$ & $\begin{array}{c}\text { Lettuce - } \\
\text { Lactuca sativa } \\
\text { L. }\end{array}$ & $\begin{array}{c}\text { red:blue: } \text { white }= \\
5: 2: 1\end{array}$ & 2500 & 25 & 100 & DI & $16 / 8$ \\
\hline $\begin{array}{l}\text { [16] Harun } \\
\text { et al. (2013) }\end{array}$ & $\begin{array}{c}\text { Lettuce - } \\
\text { Brassica C. }\end{array}$ & $\begin{array}{l}16 \text { Red } 660 \mathrm{Nm} \text {, } \\
\text { 4 Blue } 460 \mathrm{Nm}\end{array}$ & $\begin{array}{c}\text { not } \\
\text { discl. }\end{array}$ & 75 & 100 & Pho & $\begin{array}{c}0,45 / 0,1 \\
5 * 24 \\
\end{array}$ \\
\hline $\begin{array}{c}{[48]} \\
\text { Timothy et } \\
\text { al..., 2016 } \\
\end{array}$ & $\begin{array}{c}\text { Lettuce - } \\
\text { Lactuca sativa } \\
\text { L. } \\
\end{array}$ & $\begin{array}{l}16 \text { Red } 660 \mathrm{Nm} \text {, } \\
4 \text { Blue } 460 \mathrm{Nm}\end{array}$ & $\begin{array}{c}\text { not } \\
\text { disclo } \\
\text { sed } \\
\end{array}$ & 75 & 38,8 & I & $\begin{array}{c}0,45 / 0,1 \\
5 * 24\end{array}$ \\
\hline $\begin{array}{l}\text { [19] Iersel } \\
\text { et al.2016 }\end{array}$ & $\begin{array}{c}\text { Lettuce - } \\
\text { Lactuca sativa } \\
\text { L. }\end{array}$ & $\begin{array}{l}\text { 4X100 W white } \\
\text { LED }(3000 \mathrm{~K})\end{array}$ & 1000 & $\begin{array}{c}50- \\
\text { varied }\end{array}$ & $\begin{array}{c}380- \\
520 \\
\text { varied }\end{array}$ & DI & $12 / 12$ \\
\hline $\begin{array}{l}\text { [45] Son et } \\
\text { al. }(2018)\end{array}$ & $\begin{array}{c}\text { Lettuce - } \\
\text { Lactuca sativa } \\
\text { L. }\end{array}$ & $\begin{array}{c}\text { red } 655 \mathrm{Nm}, \\
\text { white } 456 \mathrm{Nm} \\
+558 \mathrm{Nm} \\
\text { blue } 456 \mathrm{Nm} \text { LEDs } \\
(7: 2: 1)\end{array}$ & 1000 & 75 & 190 & $\mathrm{~F}$ & $12 / 12$ \\
\hline $\begin{array}{c}\text { [31] Olvera- } \\
\text { Gonzalez et } \\
\text { al. }-2013\end{array}$ & $\begin{array}{c}\text { Lettuce - } \\
\text { Lactuca sativa } \\
\text { L. }\end{array}$ & $\begin{array}{c}30 \text { Blue } 460 \pm 25 \\
\text { Nm, } \\
170 \text { Red } 660 \pm 30 \\
\mathrm{Nm}, 200 \text { watts/1 }\end{array}$ & 0,1 & 50 & 750 & $\mathrm{~F}$ & $\begin{array}{c}\text { not } \\
\text { diclosed }\end{array}$ \\
\hline $\begin{array}{c}\text { [32] Olvera- } \\
\text { Gonzalez et } \\
\text { al. }-\mathbf{2 0 1 2}\end{array}$ & $\begin{array}{l}\text { Tomato - } \\
\text { Lycopersicon } \\
\text { esculentum }\end{array}$ & $\begin{array}{c}30 \text { Blue } 460 \pm 25 \\
\mathrm{Nm}, 170 \text { Red } \\
660 \pm 30 \mathrm{Nm}, 200 \\
\text { watts/1 }\end{array}$ & 1 & 50 & 450 & $\mathrm{~F}$ & $\begin{array}{c}\text { not } \\
\text { diclosed }\end{array}$ \\
\hline $\begin{array}{c}46] \\
\text { Tennessen } \\
\text { et al.- } 1995 \\
\end{array}$ & $\begin{array}{c}\text { Tomato - } \\
\text { Lycopersicon } \\
\text { esculentum } \\
\end{array}$ & $40 \mathrm{red} 668 \mathrm{~nm}$, & $\begin{array}{l}\begin{array}{l}\text { more } \\
\text { than } \\
1000\end{array} \\
\end{array}$ & $\begin{array}{c}\text { less } \\
\text { than } \\
50 \\
\end{array}$ & 50 & FI & $16 / 8$ \\
\hline $\begin{array}{l}\text { [41] Senol et } \\
\text { al. -2016 }\end{array}$ & $\begin{array}{l}\text { Carnation - } \\
\text { Dianthus sp. }\end{array}$ & $\begin{array}{l}3 \text { Red } 615-630 \mathrm{Nm} \text {, } \\
3 \text { Red } 660 \mathrm{Nm}, \\
3 \text { Blue } 455 \mathrm{Nm} \text {, } \\
3 \text { Blue } 460-475 \mathrm{Nm}\end{array}$ & 5000 & 50 & 20 & FPha & $\begin{array}{c}\text { not } \\
\text { diclosed }\end{array}$ \\
\hline
\end{tabular}


Table 3

LED based light source driver setup data of previous projects

\begin{tabular}{|c|c|c|c|c|c|c|c|}
\hline$\frac{\text { Research }}{\underline{\text { ID }}}$ & Type of plant & $\frac{\text { LED light }}{\underline{\text { spectrum }}}$ & $\frac{\text { Freq. }}{[\mathrm{Hz}]}$ & $\frac{\text { Duty }}{\frac{\text { cycle }}{[\%]}}$ & $\frac{\text { PPFD }}{\frac{(\mu \mathrm{molm}}{\left.{ }^{2} \mathrm{~s}^{-1}\right)}}$ & Notes & $\frac{\begin{array}{c}\text { Daily } \\
\text { photope }\end{array}}{\text { riod }}$ \\
\hline $\begin{array}{c}{[44]} \\
\text { Shimada et } \\
\text { al. }-2011\end{array}$ & $\begin{array}{l}\text { Thale cress - } \\
\text { Arabidopsis } \\
\text { thaliana }\end{array}$ & $\begin{array}{l}100 \text { Red } 630 \mathrm{Nm} \text {, } \\
100 \text { Blue } 470 \mathrm{Nm} \text {, } \\
\text { in a unit (Starlet) }\end{array}$ & 2500 & 45 & 1800 & Pha & $12 / 12$ \\
\hline $\begin{array}{c}{[49]} \\
\text { Vejrazka et } \\
\text { al. -2012 }\end{array}$ & $\begin{array}{l}\text { Microalgae - } \\
\text { Chlam. } \\
\text { reinhardti }\end{array}$ & $\begin{array}{l}48 \text { Red } 630 \mathrm{Nm}, \\
48 \text { Blue } 450 \mathrm{Nm}\end{array}$ & 100 & 50 & 220 & DF & $\begin{array}{c}\text { not } \\
\text { diclosed }\end{array}$ \\
\hline $\begin{array}{c}{[50]} \\
\text { Vejrazka et } \\
\text { al. }-2013\end{array}$ & $\begin{array}{l}\text { Microalgae - } \\
\text { Chlam. } \\
\text { reinhardti }\end{array}$ & 96 Red 630Nm & $\begin{array}{c}\text { more } \\
\text { than } \\
50\end{array}$ & 10 & 115 & DF & $\begin{array}{c}\text { not } \\
\text { diclosed }\end{array}$ \\
\hline $\begin{array}{c}{[20]} \\
\text { Jannsen - } \\
2002\end{array}$ & $\begin{array}{l}\text { Microalgae - } \\
\text { Dun. } \\
\text { tertiolecta }\end{array}$ & $\begin{array}{l}1452 \text { Red } 666 \\
{[\mathrm{Nm}] 22 \text { LEDs }} \\
\text { /line }\end{array}$ & 5,31 & 50 & 445 & $\mathrm{~F}$ & $16 / 8$ \\
\hline $\begin{array}{l}\text { [52] Yago et } \\
\text { al. - 2012 }\end{array}$ & $\begin{array}{l}\text { Micoralgae - } \\
\text { Isochrysis g. }\end{array}$ & $\begin{array}{l}\text { White }-400-800 \\
\text { Nm, LED panels }\end{array}$ & 10000 & 50 & 104 & FI & $12 / 12$ \\
\hline $\begin{array}{r}\text { [34] Park } \\
\text { et al. -2001 }\end{array}$ & $\begin{array}{l}\text { Microalgae - } \\
\text { Chlorella } \\
\text { kessleri }\end{array}$ & $180 \operatorname{Red} 680 \mathrm{~nm}$ & $\begin{array}{c}10- \\
50000\end{array}$ & 50 & 78 & DF & $\begin{array}{c}\text { not } \\
\text { diclosed }\end{array}$ \\
\hline $\begin{array}{l}\text { [42] Sforza } \\
\text { et al, - } 2012\end{array}$ & $\begin{array}{l}\text { Microalgae - } \\
\text { Nannoch. } \\
\text { salina } \\
\end{array}$ & $\begin{array}{l}\text { 750nm - LED Light } \\
\text { Source SL } 3500\end{array}$ & 30 & 33 & 120 & FI & $\begin{array}{c}\text { not } \\
\text { diclosed }\end{array}$ \\
\hline $\begin{array}{c}{[43]} \\
\text { Simionato } \\
\text { et al. -2013 } \\
\end{array}$ & $\begin{array}{l}\text { Microalgae - } \\
\text { Nannoch. } \\
\text { salina } \\
\end{array}$ & $\begin{array}{l}\text { 750nm - LED Light } \\
\text { Source SL } 3500\end{array}$ & 30 & 33 & 120 & ID & $\begin{array}{c}\text { not } \\
\text { diclosed }\end{array}$ \\
\hline $\begin{array}{c}\text { [53] Yago et } \\
\text { al. - } 2014\end{array}$ & $\begin{array}{l}\text { Micoralgae - } \\
\text { Isochrysis g. }\end{array}$ & 470 blue & 10000 & 50 & 52 & $\mathrm{~W}$ & $12 / 12$ \\
\hline
\end{tabular}

The summary of the best results (Table 4), shows that there were several optimal power regulators (mostly PWM) settings for each plant types. The plants are grouped to clusters of sub-types which are noted with addition mark in brackets. The number in the brackets after a plant shows the number of sub-types per plant.

Table 4

Summary of driver settings of different plants about the most efficient settings

\begin{tabular}{|c|c|c|c|}
\hline $\begin{array}{c}\text { Plant type (number of } \\
\text { researches ) }\end{array}$ & $\begin{array}{c}\text { PWM } \\
\text { Duty } \\
\text { cycle }\end{array}$ & Frequency & Light Intensity (PPFD) \\
\hline Potato (2) & 50 & 720 & 120 \\
\hline Cucumber (1) & 50 & 2500 & 120 \\
\hline Lettuce $(6+1)$ & $20 / 25 / 50$ & $0.1 / 0.2 / 50 / 1000 / 2500$ & $80 / 100 / 125 / 127 / 133$ \\
\hline Tomato (3) & 50 & $0.1 / 1 / 1000$ & $20 / 100 / 750$ \\
\hline Carnation (1) & 50 & 5000 & 20 \\
\hline Thale Cress (1) & 45 & 2500 & 20 \\
\hline $\begin{array}{l}\text { Microalgae } \\
(2+2+1+1+1)\end{array}$ & $\begin{array}{c}10 / 25 / 50 / \\
60\end{array}$ & $\begin{array}{c}5.3 / 10 / 50 / 100 / 10000 / 25 \\
000 / 50000\end{array}$ & $104-200-220-1800$ \\
\hline
\end{tabular}




\section{Statistical Analysis}

Statistical analysis has been conducted with the help of SPSS (Ver. 20) to find out if there is any significant relationship between the parameters of the experiments. First, the relevant experiments have been collected. Second, the necessary data were collected from the articles. The following variables were used in the analysis: PWM duty cycle, Frequency, Light intensity (PPFD), Light spectrum and Photoperiod. These parameters are suggested by other researches as main parameters as well [6]. As third step, the data were prepared for the descriptive statistical analysis (with the help of section 3 as well). The light spectrum variable is a simplification: it shows the percentage of RED light used in the light sources in the cited experiments. The data were acquired based on Table 3. All these parameters represent the best possible settings to achieve the best results in plant cultivation (under certain conditions). The parameters were "competing" against each other in their own experimental settings. Each of them "won" in their own environment. Therefore, it is not necessary to take into account other variables: all the conditions in the experiment. Fourth, the clustering of the experiments has been done (characterized by their best settings) according to plant types and tested variables. In the end, the statistical analysis has been conducted according to the parametric and non-parametric part of the paper to find significant relationships among variables. Smaller groups $(\mathrm{N}<6)$ have been ignored because the reliability of the data they provide is low.

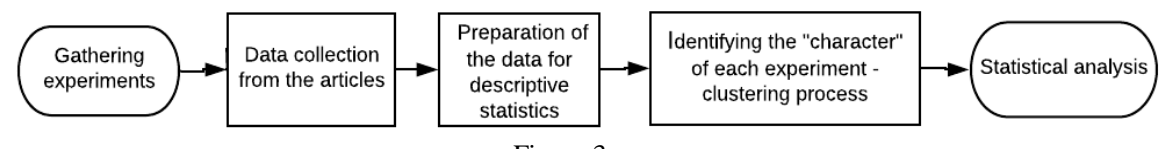

Figure 3

The process of correlation finding across experiments

\subsection{Parametric and Non-Parametric Tests}

If it is possible to make certain assumptions about a sample, it is possible to apply a parametric test. Such tests are the Pearson's $r$ or ANalysis Of Variance (ANOVA) [54]. Among other assumptions, the population of the test has to have a normal distribution. If it is not the case, the results of the tests will be false. Therefore, the distribution of the data set has to be checked in order to avoid false results. Normal distribution has very specific traits. It is a unimodal, symmetrical curve, with exact areas from the mean after each standard deviation (SD): $\pm 1 \mathrm{SD} 68.3 \%, \pm 2 \mathrm{SD}$ 95.4\%, \pm 3 SD 99.7\% (in SPSS: graphs/leg.dialogs/histogram).

The Pearson's $r$ correlation could be calculated with the following equation [2]:

$$
r=\frac{\Sigma\left(x_{i}-\bar{x}\right)\left(y_{i}-\bar{y}\right)}{\sqrt{\left[\left(x_{i}-\bar{x}\right)^{2}\right]\left[\left(y_{i}-\bar{y}\right)^{2}\right]}}
$$


Non-parametric correlational tests had been conducted with Kendall's tau (rank test - correlation signed with $r_{\tau}$ ) and also with Spearman's rho $\left(r_{\rho}\right)$ to check for error in the data set. The above mentioned tests were chosen because the variables are continuous and it can be assumed that no specific distribution exists among the specified results of the studies. The statistics take care of the wide variances of the results via giving ranks to the different magnitudes of results. Also, the size of the sample is quite small $(\mathrm{N}=25$ examined studies -2 omitted experiments because of missing data) - and the distribution of the values are quite wide (therefore Kendall's tau is suggested according to these values as well). Although, Kendall's tau does not take into account tied cases (same values) on dependent or independent variables, therefore most of the times (and in statistical software) Kendall's tau b version is used [2]:

$r_{\tau_{b}}=\frac{N_{c}-N_{d}}{\sqrt{\left(N_{c}+N_{d}+T_{y}\right)\left(N_{c}+N_{d}+T_{x}\right)}}$

Where $T_{y}$ represents the cases tied on the independent variable while the $T_{x}$ represents the cases tied on the dependent variable. Spearman' rho could be calculated with the equation [26]

$r_{p}=1-\frac{6 \sum_{i=0}^{m} d_{i}^{2}}{n\left(n^{2}-1\right)}$

Where $d_{i}$ is the difference between the ranks of the corresponding values. The two methods gave similar results, therefore Spearman's rho is more prone to errors and outliers [3]. It is suggested to use the results of Kendall's tau b.

\section{Results}

There was no significant relationship between the variables of all the experiments $(n=25)$. This was anticipated to happen, because of the differences in plants and the experimental setups. There was no significant relationship among the experiments made with the tests of Duty cycle $(\mathrm{N}=11)$ and Light Spectrum $(\mathrm{N}=2)$. Even though significant relationships were found between variables among the experiments made with the tests of Photoperiod $(\mathrm{N}=4)$, the results were not reliable because of the too low number of cases.

Significant relationship (inverse proportionate) has been found with the Parametric Pearson's $r$ correlation test between light intensity and photoperiod among the variables found in the studies conducted on lettuce $\left(\mathrm{N}=10 ; \mathrm{r}=-0.824 ; \mathrm{p}_{\mathrm{tb}}<0.003\right.$ (2tailed)), (Figure 4). Normal distribution was checked via graphical test (Figure 5).

$\underline{\text { Significant relationship (inverse proportionate) has been found between light }}$ intensity and frequency in the studies conducted on microalgae $\left(\mathrm{N}=8 ; \mathrm{r}_{\tau \mathrm{b}}=-0.679\right.$; $\left.\left(r_{\rho}=-0.812\right) ; p_{\tau b}<0.023\left(p_{\rho}<0.014\right)\right)$. (Figure 6). 
$\underline{\text { Significant relationship (inverse proportionate) has been found between light }}$ intensity and frequency in the studies conducted with the test of frequency $(\mathrm{N}=15$; $r_{\tau b}=-0.522 ;\left(r_{\rho}=-0.662\right) ; p_{\tau b}<0.008\left(p_{\rho}<0.007(2\right.$-tailed $\left.)\right)$. (Figure 7).

$\underline{\text { Significant relationship (inverse proportionate) has been found between light }}$ intensity and photoperiod in the studies conducted with the test of Light intensity $\left(\mathrm{N}=7 ; \mathrm{r}_{\tau b}=-0.738 ;\left(\mathrm{r}_{\rho}=-0.833\right) ; \mathrm{p}_{\mathrm{\tau b}}<0.028\left(\mathrm{p}_{\rho}<0.02\right.\right.$ (2-tailed)). (Figure 8) and also between light intensity and light spectrum $\left(\mathrm{N}=7 ; \mathrm{r}_{\mathrm{\tau b}}=-0.843 ;\left(\mathrm{r}_{\rho}=-0.935\right) ; \mathrm{p}_{\mathrm{\tau b}}<\right.$ $0.011\left(\mathrm{p}_{\rho}<0.001\right.$ (2-tailed)). (Figure 9).

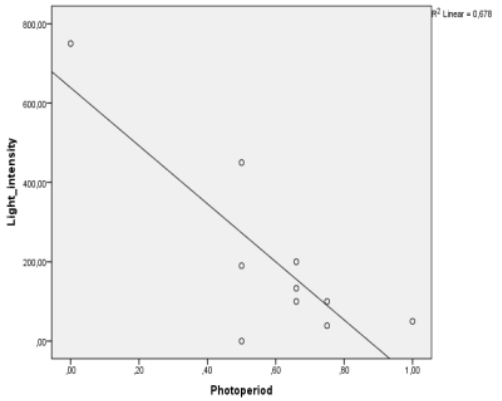

Figure 4

Significant rel. between light intensity \& photoperiod on the experiments made on lettuce - Eq. 6.

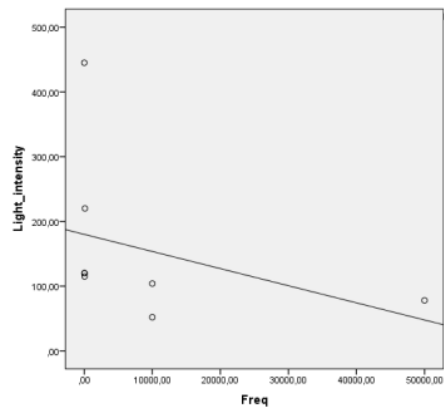

Figure 6

Significant rel. between light intensity and freq. on the experiments made on microalgae - Eq. 7

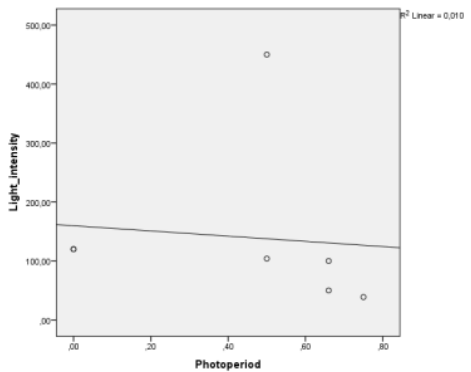

Figure 8

Significant rel. between light intensity and photoperiod on the experiments made on all the plants conducted with the test of light intensity - Eq. 7

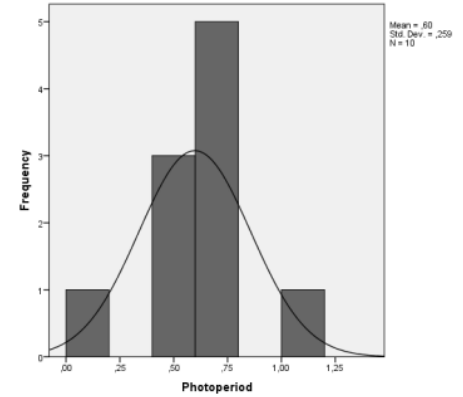

Figure 5

Normal Distribution test of variable Photoperiod (on the experiments made on lettuce

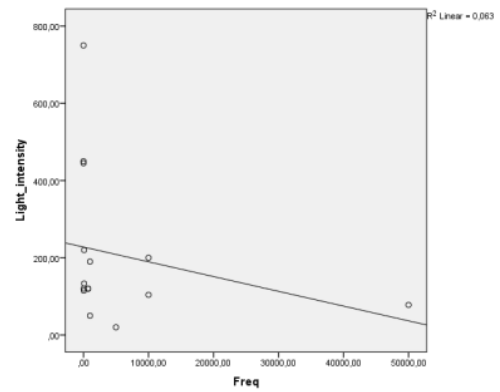

Figure 7

Significant rel. between light intensity and frequency on the experiments made on all the plants conducted with the test of frequency - Eq. 7

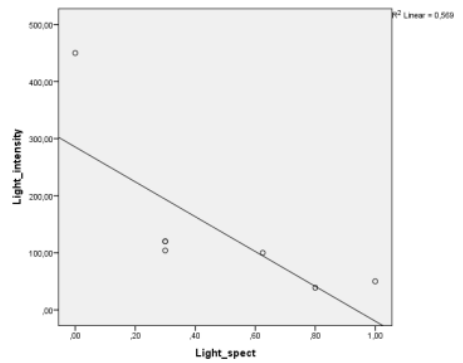

Figure 9

Significant rel. between light intensity and light spectrum on the experiments made on all the plants conducted with the test of light intensity - Eq. 7 
Light intensity (PPFD) has significant correlation with other variables almost in every analyzed group. Because it is proportional to the energy used by a light source, the variables correlated with it could be used to reduce the energy costs of a plantation - to enhance efficiency. Photoperiod, frequency and light spectrum are the variables found by this research as the variables affecting the amount of light intensity necessary.

Different plants might require a different wavelength of light (Table 3). With the right spectrum of light, not just plant growth, but energy costs could be lowered as well. Therefore, light equipment could be made with flexible spectral parameters or the light equipment has to be made for a special type of plant. Wavelength and frequency of a light source could be different in the case of different plants (Table $4)$.

\section{Conclusions}

The statistical analysis gave consistent results to other studies [6] and highlighted the correlations for the main parameters of LED light sources.

This type of statistical analysis can support light source design and the setup of agricultural facilities. It has synthesized the results of different experiments. PWM driving of light sources, with optimal settings (frequency, duty cycle, PPFD, spectrum and photoperiod) better yields of plant growth and lower running costs could be obtained.

\section{References}

[1] A. V. Arecchi, T. Messadi, and R. J. Koshel, "Field Guide to Illumination", SPIE, Bellingham, WA, USA., 2007

[2] G. Argyrous, "Statistics for research: With a guide to SPSS" (2nd ed.), London: Sage Publications. 2005

[3] S. Arndt, C. Turvey and N. C. Andreasen, "Correlating and predicting psychiatric symptom ratings: Spearman's $r$ versus Kendall's tau correlation", Journal of Psychiatric Research, 1999, 33(2), pp. 97-104

[4] I. Ashdown, "Extended parallel pulse code modulation of LEDs", Proceedings of SPIE, 2006, Vol. 6337, pp. 1-10

[5] N. R. Baker, "Chlorophyll fluorescence: a probe of photosynthesis in vivo", Annual Review of Plant Biology, 2008, Vol. 59, pp. 89-113

[6] Y. A. Berkovich, I. O. Konovalova, S. O. Smolyanina, A. N. Erokhin, O. V. Avercheva, E. M. Bassarskaya and I. G. Tarakanov, "LED crop illumination inside space greenhouses", REACH - Reviews in Human Space Exploration, Vol. 6, 2017, pp. 11-24 
[7] A. P. Carvalho, S. O. Silva, J. M. Baptista and F. X. Malcata, "Light requirements in microalgal photobioreactors: an overview of biophotonic aspects", Application Microbiology Biotechnol (2011) 89:1275-1288

[8] K. J. Cho, J. Y. Cho, I. S. Park and O. Wook, "Effects of Duty Ratio of Pulsed LED Light on Growth and Photosynthetic Rate of Lettuce Grown in a Plant Factory System", J. Korean Soc. People Plants Environ., 2013, Vol. 16 No. 6: pp.: 427-434

[9] G. Cramer, K. Urano, S. Delrot, M. Pezzotti and K. Shinozaki, "Effects of abiotic stress on plants: a systems biology perspective", BMC Plant Biology 2011, 11, pp. 163

[10] Y. L. Feng, K. F. Cao, and J. L. Zhang, "Photosynthetic Characteristics, Dark Respiration, and Leaf Mass Per Unit Area in Seedlings of Four Tropical Tree Species Grown Under Three Irradiances", Photosynthetica, Vol. 42, 2004, pp. 431-437

[11] K. M. Folta, and S.A. Maruhnich, "Green light: a signal to slow down or stop", Journal of Experimantal Botany, Vol. 58, No. 12, 2007, pp. 3099111

[12] K. M. Folta, and K. S. Childers, "Light as a Growth Regulator: Controlling Plant Biology with Narrow-bandwidth Solid-state Lighting Systems", HortScience December, Vol. 43, No. 7, 2008, pp. 1957-1964

[13] S. D. Gomkale, and S. T. Zodape, "Effects of pulsed concentrated solar radiation on seeds and plants", Journal of Scientific \& Industrial Research, Vol. 58, No. 1, 1999, pp. 11-13

[14] E. Goto, "Effects of light quality on growth of crop plants under artificial lighting”, Environment Control in Biology, Vol. 41, ,No. 2, 2003, pp. 121132

[15] R. N. Hall, G. E. Fenner, J. D. Kingsley, T. J. Soltys, and R. O. Carlson, "Coherent Light Emission From GaAs Junctions", Physical Review Letters, Vol. 9, 1962, pp. 366-369

[16] A. N. Harun, N. N. Ani, R. Ahmad and N. S. Azmi, "Red and blue LED with pulse lighting control treatment for Brassica chinensis in Indoor farming", Presented at 2013 IEEE Conference on Open Systems (ICOS), Dec.2-4, Sarawak, Malaysia

[17] R. Hernández, A. Dragotakes and C. Kubota, "Pulsing Effects of Supplemental LED Lighting on Cucumber Seedlings Growth and Morphology in Greenhouse”, Acta Hort. (ISHS) 2014, 1037: p875-880

[18] N. Holonyak, and S. F. Bevacqua, "Coherent (visible) Light Emission from Ga(As1-xPx) Junctions”, Applied Physical Letters, Vol. 1, No. 82, 1962 
[19] M.W. Iersel, E. Mattos, G. Weaver, R.S. Ferrarezi, M.T. Martin and M. Haidekker, "Using chlorophyll fluorescence to control lighting in controlled environment agriculture". Acta Hort. (ISHS), 2016, Vol. 1134, pp. 427-434

[20] M. G. J. Janssen, "Culivation of microalgae: effect of light/dark cycles on biomass yield", Doctoral Thesis, Wageningen University, Wageningen, The Netherlands, 2002

[21] R.-C. Jao and W. Fang, "An Adjustable Light Source for Photo-Phyto Related Research and Young Plant Production", Applied Engineering in Agriculture, 2003, Vol. 19(5): pp.: 601-608

[22] R.-C. Jao and W. Fang, "Effect of frequency and duty ratio on the growth of potato plantlets in vitro using light emitting diodes", HortScience, 2004, Vol. 39(2): pp.: 375-379

[23] T. Jishi, K. Fujiwara, K. Nishino and A. Yano, "Pulsed Light at Lower Duty Ratios with Lower Frequencies is Less Advantageous than Continuous Light for CO2 Uptake in Cos Lettuce", Journal of Light \& Visual Environment, 2012, Vol. 36, No. 3, pp. 88-93

[24] Cs. Kárász, J. Kopják, "Comparative study about LED driving methods and feedback system for indoor plant cultivation”, 17 $17^{\text {th }}$ IEEE International Symposium on Computation Intelligence and Informatics, Transactions on Power Electronics, Budapest, Hungary, 2016, pp. 219-224

[25] M. Kanechi, "Growth and Photosynthesis under pulsed lighting In Photosynthesis - From Its Evolution to Future Improvements in Photosynthetic Efficiency Using Nanomaterials", Edited by Juan Cristóbal García Cañedo and Gema Lorena López-Lizárraga, IntechOpen, 2018

[26] M. G. Kendall, "Rank correlation methods", (1970), London, Griffin

[27] J. Masojidek, M. Koblizek and G. Torzillo, "Photosynthesis in microalgae" In: Richmond A (ed) Handbook of microalgal culture: biotechnology and applied phycology. Blackwell Science, Oxford, 2004, pp. 20-39

[28] Y. Mori, M. Takatsuji and T. Yashuoka, "Effects of Pulsed White LED Light on the Growth of Lettuce", Shokubutsu Kojo Gakkaishi, 2002, 14(3): pp.:136-140

[29] A. Möglich, X. Yang, R. A. Ayers and K. Moffat, "Structure and function of plant photoreceptors", Annual Review of Plant Biology, Vol. 61, 2010, pp. 21-47

[30] L. Nedbal, V. Tichy, F. Xiong and J.U. Grobbelaar, "Microscopic green algae and cyanobacteria in high-frequency intermittent light"., Journal of Applied Physics, Vol. 8, 1996, pp. 325-333 
[31] E. Olvera-Gonzalez, D. Alaniz-Lumbreras, R. Ivanov-Tsonchev, J. VillaHernández, C. Olvera-Olvera, E. González-Ramírez, M. Araiza-Esquivel, V. Torres-Argüelles and V. Castaño, "Intelligent lighting system for plant growth and development", Computers and Electronics in Agriculture, Vol. 92, 2012, pp. 48-53

[32] E. Olvera-Gonzalez, D. Alaniz-Lumbreras, R. Ivanov-Tsonchev, J. VillaHernández, C. Olvera-Olvera, E. González-Ramírez, M. Araiza-Esquivel, V. Torres-Argüelles and V. Castaño, "Chlorophyll fluorescence emission of tomato plants as a response to pulsed light based LEDs", Plant Growth Regulation, 2013, Volume 69, Issue 2, pp 117-123

[33] G. P. Pardo, S. T. Velázquez, A. Cruz-Orea, C. H. Aguilar, F. Arturo, D. Pacheo and F. R. Martínez, "Pulsed led light in germination and growth of lettuce seeds", Bothalia Journal, 2017, Vol. 46, No. 4, Apr 2016, pp. 13-26

[34] K.-H. Park, and C. G. Lee, "Effectiveness of flashing light for increasing photosynthetic efficiency of microalgal cultures over a critical cell density”, Biotechnology and Bioprocess Engineering, 2001, Vol. 6(3): pp. 189-193

[35] A. C. Parr, "The Candela and Photometric and Radiometric Measurements", Journal of Research of the National Institute of Standards and Technology, Vol. 106, 2000, pp. 151-186

[36] A. Ryer, "Light Measurement Handbook", Int. Light, Newburyport, MA, 2000

[37] A. Sato and M. Tsukada, "Measuring method for photosynthetic photon flux density using a digital camera", Acta Hortic. Vol. 1170, No. 125, 2017, pp. 973-980

[38] E. F. Schubert, "Light-emitting diodes", $2^{\text {nd }}$ Ed., Cambridge Univ. Press, NY, 2006

[39] J. Schwiegerling, "Field Guide to Visual and Ophthalmic Optics", SPIE Press, Bellingham, Washington, USA, 2004

[40] R. Senol and K. Taşdelen, "A New Approach for LED Plant Growth Units”, Acta Polytechnica Hungarica, 2014, Vol. 11, No. 6

[41] R. Senol, S. Kilic and K. Tasdelen, "Pulse timing control for LED plant growth unit and effects on carnation", Computers and Electronics in Agriculture, 2016, Vol. 123, pp.: 125-134

[42] E. Sforza, D. Simionato, G. M. Giacometti, A. Bertucco and T. Morosinotto, "Adjusted Light and Dark Cycles Can Optimize Photosynthetic Efficiency in Algae Growing in Photobioreactors", . PLoS ONE, 2012, Vol. 7(6), p1-10 
[43] D. Simionato, S. Basso, G. M. Giacometti and T. Morosinotto, "Optimization of light use efficiency for biofuel production in algae", Biophysical Chemistry, Vol. 182, No. 1, 2013, pp. 71-78

[44] A. Shimada and Y. Taniguchi, "Red and blue pulse timing control for pulse width modulation light dimming of light emitting diodes for plant cultivation", Journal of Photochemistry and Photobiology B: Biology, 2011, Vol. 104, No, 3, pp.: 399-404

[45] K.-H. Son, S.-R. Lee and M.-M. Oh, "Comparison of lettuce growth under continuous and pulsed irradiation using light-emitting diodes", The Korean Society of Horticulture, Horticultural Science and Technology, 2018, Vol. 36, No. 4 pp. $542-551$

[46] D. J. Tennessen, R. J. Bula and D. Sharkey, "Efficiency of photosynthesis in continuous and pulsed light emitting diode irradiation", Photosynthesis Research, 1995, Volume 44, Issue 3, pp. 261-269

[47] Thorlabs, "Light emitting diode technologies", Thorlabs Inc, .Newton, New Jersey, United States p. 506

[48] M. Timothy, C. Ira and W. John, "Horticulture of lettuce (Lactuvasativa L.) using red and blue led with pulse lighting treatment and temperature control in SNAP hydroponics setup", Journal Teknologi (Sciences \& Engineering), 2016, Vol. 78, No. 9, pp. 67-71

[49] C. Vejrazka, M. Janssen, M. Streefland and R. H. Wijffels, "Photosynthetic efficiency of Chlamydomonas reinhardtii in attenuated, flashing light", Biotechnology and Bioengineering; 2012, Vol. 109, No. 10, pp.: 2567-74

[50] C. Vejrazka, M. Janssen, G. Benvenuti, M. Streefland and R. H. Wijffels, "Photosynthetic efficiency and oxygen evolution of Chlamydomonas reinhardtii under continuous and flashing light", Applied Microbiology\&Biotechnology, 2013, Vol. 97, pp: 1523-1532

[51] J. Whitmarsh and Govindjee, "Photosynthesis". In: Encyclopedia of Applied Physics. Wiley; 1995, Vol. 13, pp. 513-532

[52] T. Yago, H. Arakawa, K. Fukui, B. Okubo, K. Akima, S. Takeichi, Y. Okumura and T. Morinaga, "Effects of flashing light from light emitting diodes (LEDs) on growth of the microalga Isochrysis galbana", African Journal of Microbiology Research 2012, Vol. 6(30), pp. 5896-5899

[53] T. Yago, H. Arakawa, K. Akima, Y. Okumura and T. Morinaga, "Effects of flashing light-emitting diode (LED) of several colors on the growth of the microalga Isochrysis galbana", African journal of microbiology research., 2014, Vol. 8., pp. 3815-3820 
[54] J. Zheng, W. Zhuang, N. Yan, G. Kou, H. Peng, C. McNally, D. Erichsen, A. Cheloha, S. Herek and C. Shi, "Classification of HIV-1-mediated neuronal dendritic and synaptic damage using multiple criteria linear programming”, Neuroinformatics. 2004, Vol. 2(3), pp. 303-26. 